\title{
Effectiveness of an Educational Program for Management of Patients Undergoing Permanent Pacemaker on Nurses' Performance
}

\author{
Hoda Abdel Monem Elsebai ${ }^{1}$, Marwa Mostafa Ragheb ${ }^{2}$ and Samah Elsayed Ghonaem ${ }^{3}$ \\ (1) Instructor at Mansoura Technical Health Institute , Egypt , (2) Professor of Medical Surgical \\ Nursing, Faculty of Nursing, Benha University, Egypt and (3) Assist Professor of Medical Surgical \\ Nursing, Faculty of Nursing, Benha University, Egypt
}

\begin{abstract}
Background: Pacemaker is the recommended therapy for treating the conduction system disorders. Aim of this study: Was to evaluate the effectiveness of an educational program for management of patients undergoing permanent pacemaker on nurses' performance. Design: Quasi experimental design was utilized. Setting: This study was conducted in the Coronary Care Unit and Cardiac Catheterization Unit at Benha university hospital. Sample: All available nurses were included (42) nurses. Data collection tools: Two tools were used, I: A structural interview to assess studied nurses' demographic characteristics and knowledge about nursing management of patients undergoing permanent pacemaker and II: Observational checklist to observe nurses' practice about nursing management of patients undergoing permanent pacemaker. Results: Two thirds of nurses had poor total knowledge pre-program implementation whenever, more than two thirds of nurses had a good total knowledge post-program implementation and more than half of them had a good total knowledge on follow-up post program implementation. The majority of studied nurses had un satisfactory level of practice pre-program implementation whenever, nearly two thirds of them had a satisfactory level of practice post-program implementation and more than half of them had a satisfactory total practice follow-up program implementation. Conclusion: A statistically significant improvement in nurses' knowledge and practice immediately and after two months compared to their baseline assessment. Recommendation: Continuous educational programs for nurses based on evidence to improve their knowledge and practice related to pacemaker.
\end{abstract}

Keywords: Educational program, Nursing performance, Pacemaker.

\section{Introduction}

Permanent Pacemaker (PM) is an implantable device used to maintain sufficient heart rate when natural mechanisms fail, either as a result of a deficiency with the natural PM or the conduction system in the heart. The impaired cardiac rhythm is initiated and maintained through cardiac pacing where very low electrical energies are delivered to the heart repetitively. Pacing may be temporary, with an external pulse generator, or permanent, with an implanted pulse generator. More recently, the indications for cardiac pacing have extended beyond symptomatic bradycardia and include conditions such as hypertrophic obstructive cardiomyopathy and prevention of atrial fibrillation (Dalia \& Amr, 2020).

Caring of these patients requires knowledge about the device and its complications and the related factors and also the patient's hemodynamic condition, nurses' information and knowledge can be crucial and constructive in patients' training and hence the reduction of complications during the life with device .Providing nursing care and 
proper nursing processes for these patients can prevent complications and defects in the device performance (Ebada, Elsenousy, Mohamed \& Abdelatief, 2017).

The nurse should also explain the operation for the patient not only for the purposes of consent but it was found that preoperative information has a positive effect on patients postoperatively. It reduces the patient's experience of pain and anxiety. Preoperative explanations are important for the patient and relatives to know what to expect with regard to invasive lines, site of dressing, possible connections to monitor and all post-operative surrounding environment and expected procedures (WHO, 2017).

\section{Significance of the study}

Pacemaker implantation saves many lives and returns patients to better health and full productive life. It implies physical, psychological, social and spiritual issues, even if the pacing is a complete success. There are about 3 million people worldwide with pacemaker and each year 600,000 pacemakers are implanted. Taking care of such a rapidly growing patient population constitutes a challenge for all health care providers working in a cardiology ward, operating room or primary care practice (Catalan-Matamoros, Lopez-Villegas, Tore-Lappegard\& Lopez-Liria, 2019).

According to the manual statistical records for admitted patients in Benha university hospital, the total number of patient is 140 in 2020(Benha Annual Statistical Records, 2020).

\section{Aim of the study \\ The aim of this study was to evaluate the effectiveness of an educational program for}

management of patients undergoing permanent pacemaker on nurses' performance.

\section{Research Hypothesis:-}

There would be significant improvement in nurses' performance after implementing the educational program than before.

\section{Subjects and method}

\section{Research design:}

Quasi-experimental design (pre-test, post-test $\&$ follow-up) was utilized to conduct this study.

\section{Setting:}

This study was conducted at the Coronary Care Unit and Cardiac Catheterization Unit in Benha university hospital.

\section{Subjects:}

A convenient sample of nurses (total number is 42 nurses including 12 nurses in cardiac catheterization unit and 30 nurses at coronary care unit at Benha University Hospital) with different sex, age, qualification and years of experiences who provide nursing care for patients undergoing permanent pacemaker.

\section{Tools of Data Collection:-}

Data was collected by using the following two tools:

\section{Tool 1:- A structural Interviewing Questionnaire:}

It was developed through review of literature and aimed to assess the nurses' demographic characteristics and knowledge. It consists of two main parts:

\section{Part (1): Socio demographic}

\section{Characteristics of the Studied Nurses}

Included questions related to personal characteristic of the study subjects which composed of (5) questions including sex, age, qualifications, years of experiences, attending 
training sessions on how to provide nursing care for patients undergoing permanent pacemaker.

Part (2): Nurses' knowledge about nursing management of patients undergoing permanent pacemaker.

Nurses' knowledge about heart anatomy, definition of pacemaker, components of pacemaker, types of pacemaker, complications of pacemaker, nursing management for patients undergoing permanent pacemaker included 46 questions in the form of true or false and choosing the correct answer.

\section{Scoring system:}

For the pacemaker interview sheet each correct answer was given score of one while incorrect answer or don't know was given zero. The answers of nurses were evaluated using model answer prepared by the investigator. For each part, the score of the items were summed up and divided by the total of items, giving a mean score of the part. These scores were converted into percent score. All scores were transformed into score $\%$ as follows:

Score $\%=$ (the nurse score/ total score $) \times 100$ Then score $\%$ was transferred into categories as follows:

\section{Knowledge categories:}

- For 75-100\% was considered good level of knowledge (35-47 degree).

- $\quad$ For $60-<75 \%$ was considered average level of knowledge (28-35< degree).

- For less than 60\% was considered poor level of knowledge ( $<28$ degree).

Tool II: -Observational checklist to observe nurse's practice about nursing management of patients undergoing permanent pacemaker.

It was adopted from (Jacob et al., 2015), and modified by the researcher after review of related literature. Permanent pacemaker practice checklists consist of (6) main parts covering all the procedure related to permanent pacemaker nursing procedures and consists of (116) questions which included the following categories:

Part 1: Patient preparation, it included (15) steps.

Part 2: post implantation care, it included (9) steps.

Part 3: wound care, it included (17) steps.

Part 4: measuring radial pulse. It included (13) steps.

Part 5: electrocardiogram, it included (30) steps.

Part 6: intravenous cannula insertion, it include (32) steps.

\section{Scoring system:}

For pacemaker practice items, the item done was scored one and not done was scored zero for each item, the scored items were summed up and the total divided by the number of the items, giving mean score. All scores were transformed into score $\%$ as follow:

- The observed nurse score $=$ score of performance checklist

- The maximum score $=$ total score of the performance checklist

- Score $\%=$ (score of performance checklist /total score of the performance checklist) $\mathrm{x}$ 100. Then score $\%$ was transferred into categories as follow:

\section{Practice categories:}

- For $75 \%$ \& above was considered satisfactory level of practice ( $\geq 87$ degree).

- For below $75 \%$ was considered unsatisfactory level of practice $(<87$ degree). 


\section{Validity \& Reliability of Tools}

Tools of data collection were developed after reviewing the national and international Literatures related to the study, this tools modified by the researcher then tested for content validity by a panel of seven experts in the field of medical surgical nursing two of them was assistant professor and three lecturers at the faculty of Nursing, Benha University, one professor at the faculty of Nursing, Ain Shams University and one lecturer at the faculty of medicine, Mansoura university reviewed the tools for clarity, relevance, comprehensiveness, understanding, applicability and simplicity for implementation and some modification were applied accordingly.

Reliability test was made by using Cronbach's Alpha

\begin{tabular}{|c|c|c|}
\hline Tool & $\begin{array}{c}\text { No of } \\
\text { questions }\end{array}$ & $\begin{array}{c}\text { Cronbach's } \\
\text { Alpha }\end{array}$ \\
\hline Knowledge & 46 & 0.846 \\
\hline Practice & 116 & 0.941 \\
\hline
\end{tabular}

\section{Ethical Consideration:}

All relevant ethical issues were taken into consideration including the following: The research approval was obtained before starting with the program, the aim of the study was explained to each nurse and then an oral consent for participation in the study was obtained from each one of them, ensuring nurse's privacy and confidentiality of the collected data during the study. Voluntary participation as they were given an opportunity to refuse the participation, and they were assured that there information which would be used for research purposes only.

\section{Pilot study:}

Pilot study was carried out on $10 \%$ (six nurses) who were selected randomly from 42 nurses under study those nurses were then excluded from the study. The purpose of the pilot study was to ascertain the clarity and applicability of the tool and to estimate the time needed to answer the interview sheet. Based on the finding of the pilot study, modification was made to make the tool more applicable to nurses.

\section{Field Work:}

The study was implemented through the following four phases:

\section{1- Assessment Phase:}

Observing nurses' performance during pacemaker management was done in order to fill practice checklist sheets of the studied nurses. These pre-tests were done to assess the level of knowledge and practices of the study group concerning pacemaker and nursing management of patients with pacemaker before starting the educational program as baseline assessment data.

\section{2- Planning Phase:}

Once the assessment phase finished, the researcher assessed the educational needs of the nurses regarding pacemaker then went through literature review and internet searching for relevant information to construct the educational program under the guidance of the supervisors. The main aim was to improve knowledge and practices of nurses regarding nursing management of patients with pacemaker. A simple colored Arabic booklet was developed for nurses covering all items related to pacemaker and its management.

\section{3- Implementation phase:}

The educational program considered for this study has been carried out in nurses' room in the coronary care unit and cardiac catheterization unit at Benha university hospital. The implementation of the program 
was within the schedule of the nurses working hours. The subjects were divided into small groups (6 groups), each group consist of seven nurses, according to the total number of nurses (42). The program was conducted through five sessions divided into theoretical part (knowledge booklet given to each nurses' group included three sessions) and practical part ((practice booklet given to each nurses' group included two sessions), and the duration of each session was about 60 minutes.

\section{4- Evaluation phase:}

The evaluation phase focused on determining the effect of the program regarding nurses' pacemaker interview sheet and practice observational checklists using the same tools (I, II) in pre-program assessment. The evaluation was done by the following phases:-

Immediate Phase, directly after implementing the program (post-test) and continued for three months from the beginning of November 2019 to the end of January 2020. The results compared to the pretest results to evaluate the impact of the program on knowledge and practices of the nurses.

Two months later, after two months from immediate posttest and continued for three months from the beginning of February to the end of April 2020.The results compared to the previous results to evaluate the nurses' retention of knowledge and consistent of their practical learning

The study was done during morning $\&$ Afternoon shifts three times weekly during the time of the study (9 months) started from beginning of August 2019 till the end of April 2020.

$>$ Three months for pre-program data collection (from the beginning of August 2019 to the end of October 2019).
Three months for program implementation \& data collection post implementing the program (from the beginning of November 2019 to the end of January 2020).

$>$ Three months follow-up program implementation (from the beginning of February to the end of April 2020).

\section{Results}

Table (1): Shows that more than half of studied nurses aged from $18<30$ years old with mean age 28.69 and majority of them $(83.3 \%)$ were female. Regarding the level of education nearly half of them $(47.6 \%)$ graduated from technical institute of nursing, whenever more half of them $(57.1 \%)$ had less than 5 years of experience and two thirds of them (66.7\%) didn't attended scientific sessions about caring of patients undergoing pacemaker insertion.

Figure (1): illustrated that nearly than two thirds of nurses had a poor total knowledge pre-program implementation whenever, more than two thirds of nurses had a good total knowledge post-program implementation and more than half of them had a good total knowledge follow-up program implementation.

Figure (2): illustrated that the majority of studied nurses had un satisfactory total practice pre-program implementation whenever, nearly two thirds of them had a satisfactory total practice post-program implementation and more than half of them had a satisfactory total practice follow-up program implementation.

Table (2) showed that in pre-program implementation, there were statistically significant relation between sociodemographic characteristics and total knowledge in all items except for items related to level of education there were a highly statistically significant relation 
$\left(\mathrm{p}<0.001^{* *}\right)$ and items related to gender and Years of experience there were no statistically significant difference $\left(\mathrm{p}>0.05^{*}\right)$, while in post program implementation, there were a highly statistically significant relation between socio-demographic characteristics and total knowledge in all items except for item related to gender and educational level there was statistically significant relation $\left(p<0.05^{* *}\right)$. Also in follow-up program implementation, there were a statistically significant relation between socio-demographic characteristics and total knowledge in all items except for item related to attending scientific sessions there was a highly statistically significant relation $\left(\mathrm{p}<0.001^{* *}\right)$ and items related to gender, there were no statistically significant difference $(\mathrm{p}>0.05 *)$.

Table (3): Shows that there were no statistically significant relation between socio-demographic characteristics and total practice in all items. ( $\left.p>0.05^{*}\right)$ except for item related to age there was statistically significant relation $\left(\mathrm{p}<0.05^{*}\right)$ in pre-program implementation while there were statistically significant relation between sociodemographic characteristics and practice in all items except for item related to gender there was no statistically significant relation $\left(\mathrm{p}>0.05^{*}\right)$ in post program implementation. Also , there were no statistically significant relation between socio-demographic characteristics and practice in all items except for item related years of experience and attending scientific sessions there was statistically significant relation $\left(p<0.05^{*}\right)$ in follow-up program implementation.

Table (4): Shows that there was statistically significant positive correlation between total pre knowledge score regarding pace maker and their total practice at post \&follow-up program implementation whenever, there was no statistically significant correlation between total pre knowledge score regarding pacemaker and their total practice at prprogram implementation.

Table (1): Distribution of socio demographic characteristics of studied nurses $(n=42)$.

\begin{tabular}{||l|c|c|}
\hline Demographic characteristics & No & $\%$ \\
\hline Age & $\mathbf{2 5}$ & $\mathbf{5 9 . 5}$ \\
\hline $18<30$ & 16 & 38.1 \\
\hline $30<40$ & 1 & 2.4 \\
\hline $40<50$ & \multicolumn{1}{|c|}{} \\
\hline Gean= 28.69 & 7 & 16.7 \\
\hline Maler & 35 & 83.3 \\
\hline Female & 18 & 38.1 \\
\hline Educational level & $\mathbf{2 0}$ & $\mathbf{4 7 . 6}$ \\
\hline Diploma & 6 & 14.3 \\
\hline Technical institute & 24 & $\mathbf{5 7 . 1}$ \\
\hline Faculty of nursing & 11 & 26.2 \\
\hline Years of experience & $\mathbf{7}$ & 16.7 \\
\hline$<5$ years & \multicolumn{1}{|c|}{} \\
\hline 5-10 years & 14 & 33.3 \\
\hline$\geq 10$ years & 28 & 66.7 \\
\hline $\begin{array}{l}\text { Attended to scientific sessions about caring of patients undergoing pacemaker } \\
\text { insertion }\end{array}$
\end{tabular}




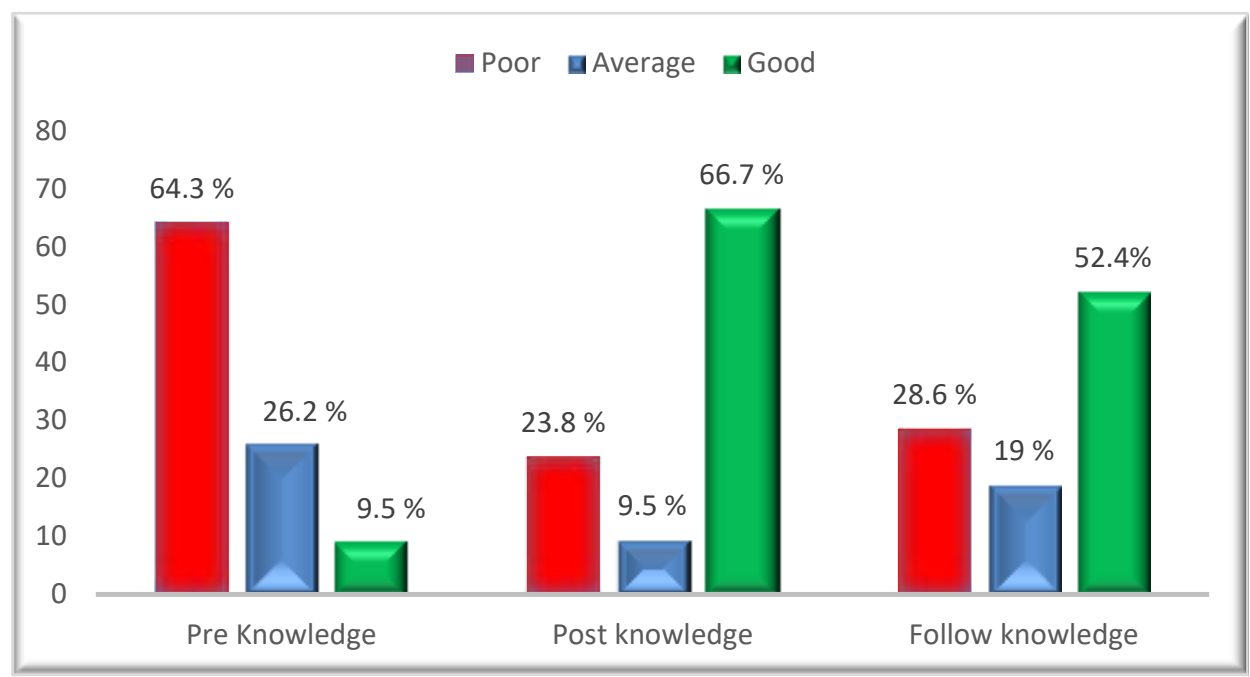

Figure (1): Distribution of studied nurses according to their total knowledge pre, post \&follow-up program implementation $(n=42)$.

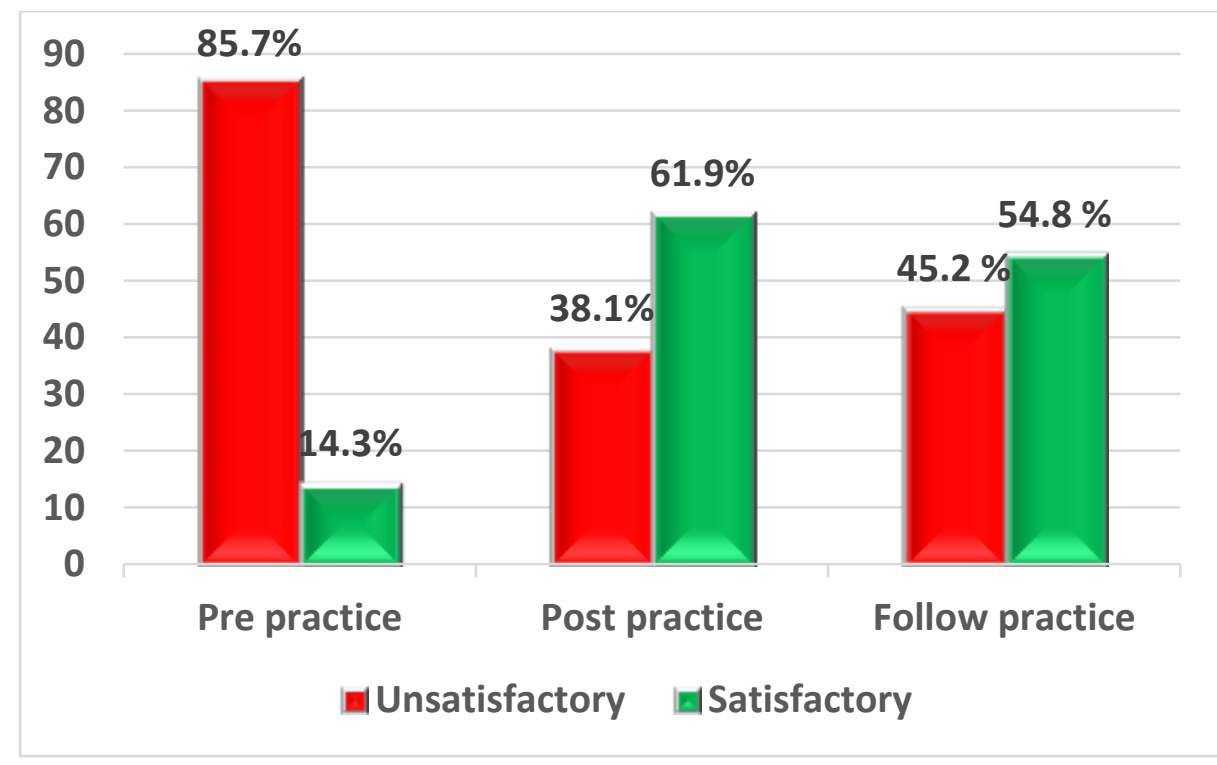

Figure (2): Distribution of studied nurses according to their total pace maker practice pre, post \&follow-up program implementation $(n=42)$. 
Effectiveness of an Educational Program for Management of Patients Undergoing Permanent

Pacemaker on Nurses' Performance

Table (2): Relation between total knowledge \&socio-demographic characteristics of nurses pre, post \& follow-up program implementation $(n=42)$.

\begin{tabular}{|c|c|c|c|c|c|c|c|c|c|c|c|c|c|c|c|c|c|c|}
\hline \multirow{3}{*}{$\begin{array}{c}\text { Demographic } \\
\text { characteristi } \\
\text { cs }\end{array}$} & \multicolumn{6}{|c|}{ Pre-program } & \multicolumn{6}{|c|}{ Post-program } & \multicolumn{6}{|c|}{ Follow-up } \\
\hline & \multicolumn{2}{|c|}{ Poor } & \multicolumn{2}{|c|}{ Average } & \multicolumn{2}{|c|}{ Good } & \multicolumn{2}{|c|}{ Poor } & \multicolumn{2}{|c|}{ Average } & \multicolumn{2}{|c|}{ Good } & \multicolumn{2}{|c|}{ Poor } & \multicolumn{2}{|c|}{ Average } & \multicolumn{2}{|c|}{ Good } \\
\hline & No & $\%$ & No & $\%$ & No & $\%$ & No & $\%$ & No & $\%$ & No & $\%$ & No & $\%$ & No & $\%$ & No & $\%$ \\
\hline \multicolumn{19}{|l|}{ Age } \\
\hline $18<30$ & 19 & 70.4 & 2 & 18.2 & 4 & 100 & 9 & 90 & 2 & 50 & 14 & 50 & 11 & 91.7 & 5 & 62.5 & 9 & 40.9 \\
\hline $30<40$ & 8 & 29.6 & 8 & 72.7 & 0 & 0 & 1 & 10 & 1 & 25 & 14 & 50 & 1 & 8.3 & 3 & 37.5 & 12 & 54.5 \\
\hline $40<50$ & 0 & 0 & 1 & 9.1 & 0 & 0 & 0 & 0 & 1 & 25 & 0 & 0 & 0 & 0 & 0 & 0 & 1 & 4.5 \\
\hline $\begin{array}{c}\text { Chi-square } \\
\text { \&P-value }\end{array}$ & \multicolumn{4}{|c|}{13.106} & 0.0 & & \multicolumn{4}{|c|}{14.842} & \multicolumn{2}{|c|}{$0.001 * *$} & \multicolumn{4}{|c|}{8.638} & \multicolumn{2}{|c|}{$0.05^{*}$} \\
\hline \multicolumn{19}{|l|}{ Gender } \\
\hline Male & 5 & 18.5 & 1 & 9.1 & 1 & 25 & 4 & 40 & 1 & 25 & 2 & 7.1 & 4 & 33.3 & 0 & 0 & 3 & 13.6 \\
\hline Female & 22 & 81.5 & 10 & 90.9 & 3 & 75 & 6 & 60 & 3 & 75 & 26 & 92.9 & 8 & 66.7 & 8 & 100 & 19 & 86.4 \\
\hline $\begin{array}{c}\text { Chi-square } \\
\text { \&P-value }\end{array}$ & \multicolumn{4}{|c|}{0.0721} & & 97 & \multicolumn{4}{|c|}{5.949} & & $5 *$ & \multicolumn{4}{|c|}{4.145} & \multicolumn{2}{|c|}{0.126} \\
\hline \multicolumn{19}{|c|}{ Educational level } \\
\hline Diploma & 15 & 55.6 & 1 & 9.1 & 0 & 0 & 8 & 80 & 2 & 50 & 6 & 21.4 & 8 & 66.7 & 3 & 37.5 & 5 & 22.7 \\
\hline $\begin{array}{c}\text { Technical } \\
\text { institute }\end{array}$ & 11 & 40.7 & 8 & 72.7 & 1 & 25 & 2 & 20 & 2 & 50 & 16 & 57.1 & 4 & 33.3 & 5 & 62.5 & 11 & 50 \\
\hline $\begin{array}{l}\text { Faculty of } \\
\text { nursing }\end{array}$ & 1 & 3.7 & 2 & 18.2 & 3 & 75 & 0 & 0 & 0 & 0 & 6 & 21.4 & 0 & 0 & 0 & 0 & 6 & 27.3 \\
\hline $\begin{array}{c}\text { Chi-square } \\
\text { \&P-value }\end{array}$ & \multicolumn{4}{|c|}{20.823} & 0.000 & & \multicolumn{4}{|c|}{11.940} & 0.01 & & & .303 & & & 0.0 & $36^{*}$ \\
\hline Years of expe & nce & & & & & & & & & & & & & & & & & \\
\hline$<5$ years & 17 & 63 & 4 & 36.4 & 3 & 75 & 10 & 100 & 1 & 25 & 13 & 46.4 & 11 & 91.7 & 5 & 62.5 & 8 & 36.4 \\
\hline $5-10$ years & 7 & 25.9 & 4 & 36.4 & 0 & 0 & 0 & 0 & 3 & 75 & 8 & 28.6 & 1 & 8.3 & 3 & 37.5 & 7 & 31.8 \\
\hline$\geq 10$ years & 3 & 11.1 & 3 & 27.3 & 1 & 25 & 0 & 0 & 0 & 0 & 7 & 25 & 0 & 0 & 0 & 0 & 7 & 31.8 \\
\hline $\begin{array}{c}\text { Chi-square } \\
\text { \&P-value }\end{array}$ & & 4.107 & & & 0.39 & & & .318 & & & 0.00 & $* *$ & & 2.687 & & & 0.01 & \\
\hline Attend scientif & ses & ions a & bou & carin & g of & atien & s un & lergoi & ng pa & cem & aker & nsert & & & & & & \\
\hline yes & 13 & 48.1 & 1 & 9.1 & 0 & 0 & 10 & 100 & 1 & 25 & 3 & 10.7 & 11 & 91.7 & 2 & 25 & 1 & 4.5 \\
\hline No & 14 & 51.9 & 10 & 90.9 & 4 & 100 & 0 & 0 & 3 & 75 & 25 & 89.3 & 1 & 8.3 & 6 & 75 & 21 & 95.5 \\
\hline $\begin{array}{c}\text { Chi-square } \\
\text { \&P-value }\end{array}$ & & 7.576 & & & 0.02 & & & 6.571 & & & $.000^{\circ}$ & & & 26.83 & & & $00 * *$ & \\
\hline
\end{tabular}

Non sig. $>0.05$ Sig. $<0.05 *$ High sig. $<0.001 * *$

(Statistical significant difference)
$\mathrm{X} 1=$ relation between pre $\&$ post program

$\mathrm{X} 2=$ relation between pre\& follow-up program 
Table (3): Relation between total practice \&socio-demographic characteristics of nurses pre, post \& follow-up program implementation $(n=42)$.

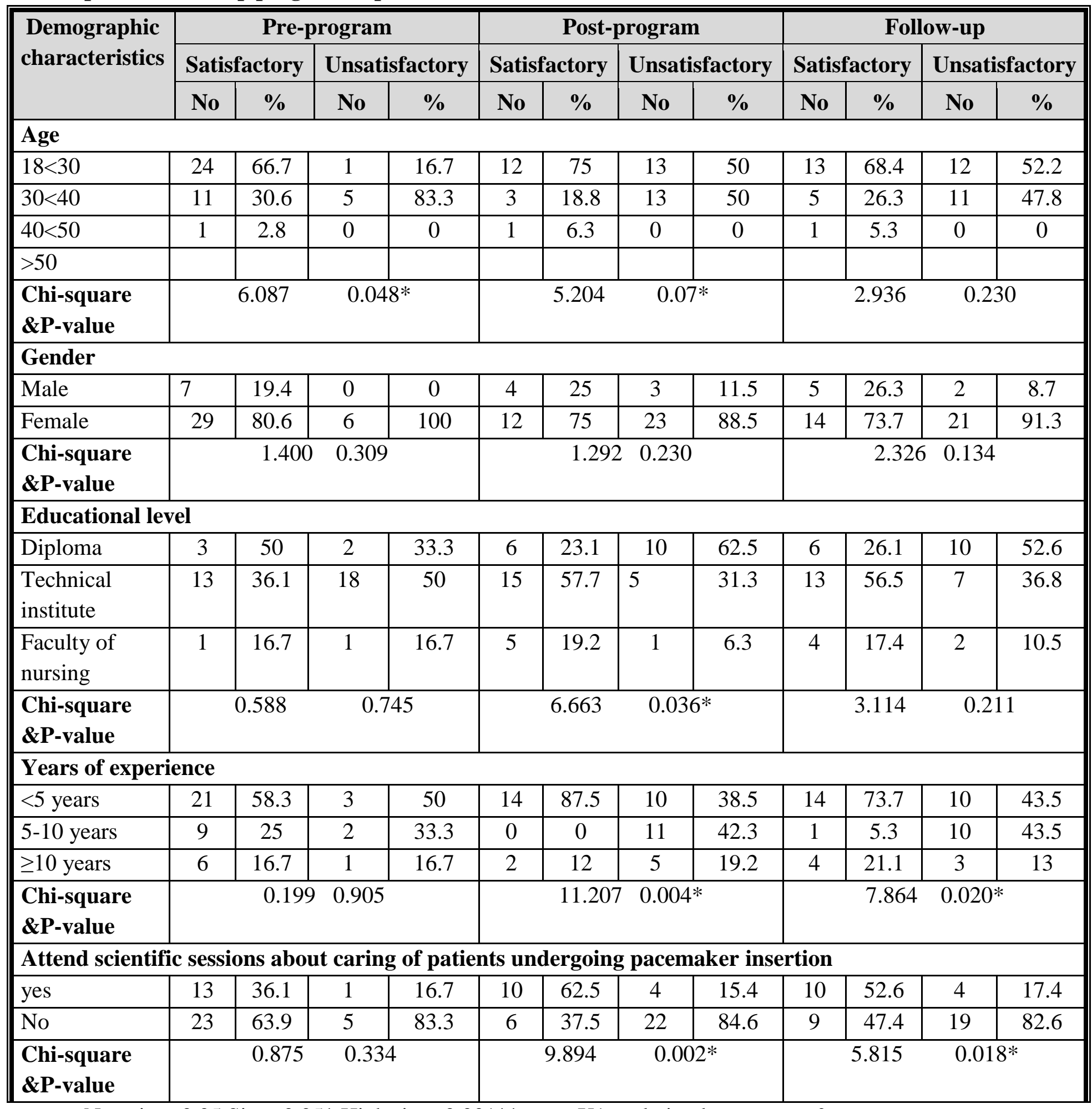

Non sig. $>0.05$ Sig. $<0.05^{*}$ High sig. $<0.001 * * \quad \mathrm{X} 1=$ relation between pre $\&$ post program

(Statistical significant difference) $\quad \mathrm{X} 2=$ relation between pre $\&$ follow-up program 
Table (4): Correlation between nurses' total knowledge regarding pace maker and their total practice pre, post $\&$ follow-up program implementation $(n=42)$.

\begin{tabular}{||c|c|c|c|c|c|c|}
\hline \multirow{3}{*}{$\begin{array}{c}\text { Total knowledge } \\
\text { score }\end{array}$} & \multicolumn{6}{|c|}{ Total practice Score } \\
\cline { 2 - 7 } & \multicolumn{2}{|c|}{ Pre program } & \multicolumn{2}{c|}{ Post program } & \multicolumn{2}{c|}{ Follow-up } \\
\cline { 2 - 7 } & $\mathrm{r}$ & $\mathrm{p}$-value & $\mathrm{r}$ & $\mathrm{p}$-value & $\mathrm{r}$ & $\mathrm{p}$-value \\
\hline Pre & 0.176 & 0.264 & $0.392^{*}$ & $0.025^{*}$ & $0.379^{*}$ & $0.018^{*}$ \\
\hline Post & $0.320^{*}$ & 0.039 & $0.454^{* *}$ & $0.001^{* *}$ & $0.402^{* *}$ & $0.001^{* *}$ \\
\hline Follow-up & 0.123 & 0.437 & $0.436^{* *}$ & $0.001^{* *}$ & $0.463^{* *}$ & $0.001^{* *}$ \\
\hline
\end{tabular}

\section{Discussion}

Cardiac pacing is an emerging lifesaving procedure that is being widely used in the recent times. Therefore, it is considered vital for the healthcare professionals to be aware of patients' knowledge and experience after the cardiac device implantation and also, the impact these implanted devices have on their day-to-day life (Snegalatha et al. 2019).

As regards to gender, the present study findings revealed that the majority of the studied nurses were females. This result could be interpreted in the light of the fact that, the majority of nurses in Egypt are females and their numbers are still greater than males in nursing fields. This finding agreed with Ali et al. (2012) whose study entitled (Effect of self learning modules on nurses performance regarding electrocardiography, Doctoral dissertation, Thesis submitted for partial fulfillment of doctorate degree, Faculty of nursing, Ain Shams University) their study indicated that, the majority of the studied sample were female.

This result disagreed with Hassan \& Aburaghif, (2016) entitled (Effectiveness of an Educational Program on Nurse's knowledge concerning Complications of Cardiac Catheterization among Children at Al-Nassirhya Heart Center) who reported that most participant of the study sample were males.

In relation to the age, the study indicated that more than half of studied nurses aged from $18<30$ years old with mean age 28.69. This may be due to the majority of nurses work power that providing direct care for the patient in nursing field in our study are young females while higher age category 'senior nurses' perform administrative role. The study is agreed with Khudur, (2019) who studied (Effectiveness of an Education Program on Nurses knowledge concerning in Nursing Management for patients with Third degree and bundle branch block in Kirkuk Teaching Hospitals) which revealed that the most of the nurses at age between (20-29 years)

In contrast Henedy \& El-Sayad, (2019) whose study entitled (Nurses' Knowledge and practice regarding patient's safety Post Cardiac Catheterization) their study indicated that; the mean age of the sample was about thirty-two years old.

Regarding to educational level, the present study revealed that nearly half of them had nursing technical institute, their experiences less than five years, This agreed with Thabet et al. (2019) entitled (Assessment of Nurses' knowledge And Practices Regarding Temporary Pacemaker patients care) who found that more than half 
of studied nurses have nursing institute degree with experience less than one year.

This disagreed with Bakr et al. (2020) entitled (Assessment Of Nurses' performance Regarding Care Of Patients Undergoing Cardiac Catheterization in Port Said) who noticed that high percentage of studied nurses had experience from 5 year to less than 10 years

\section{Regarding attends scientific} sessions; in this study the minority of studied nurses attending training courses. This may be due to lacking motivation and inability of some nurses to attend training course due to lacking of nurses' number, also they may feel that attending courses has little or no value for them and not affecting their salary, Similarly to Mohammed et al. (2020) entitled (Nurses' Performance Regarding Patient with Permanent Pacemaker in Intensive Care Unit) who revealed that, most of studied nurses didn't get training courses about caring for patient with permanent pacemaker after surgery.

This disagreed with Bakr et al. (2020) who found that most of the studied group mentioned attendance courses training. In addition, more than half of nurses reported that they attended twice to the previous courses.

The result in the present study revealed that there was a significant improvement at the post-program phase as more than two-thirds of nurses had good knowledge level regarding improvement in nurses' knowledge and more than half of them had a good total knowledge follow-up program implementation. It showed that nurses were able to learn and get correct information about pacemaker implantation as a practice of their daily work. And might be related to the fact that more than half of nurses were less than 30 years this age might have good readiness for learning new things.

These findings were in agreement with Khudur (2019) who found in her study that great improvement in knowledge score levels after implementing of the educational program.

This study showed that, there was a marked improvement in nurses' practice after implementing the educational program in comparison with their practice level before implementing the educational program as the majority of studied nurses had un satisfactory total practice pre-program implementation whenever, nearly two thirds of them had a satisfactory total practice post-program implementation and more than half of them had a satisfactory total practice follow-up program implementation.

This may be due to the effect of explaining the correct steps of pacemaker insertion nursing procedures in the educational program with colored pictures illustrating each step, using data show and implementing these steps on the patient for all study groups.

This is in harmony with Malk et al. (2018) entitled (Effect of an Education Program on Nurses Performance Regarding Electrocardiography) who reported that the majority of the studied nurses had got statistically significant improvement in their performance post the program implementation, while this improvement lowered slightly post three months at follow up, which supported the study hypothesis

The current study revealed that there was a statistical significant relation between age with total knowledge, This mean that the young nurses didn't have satisfactory level of knowledge, This might be because lack of 
knowledge and practice for recently graduated nurses rather than old graduated nurses, This finding agreed with Mohammed et al. (2020) who demonstrated that there was statistical significant relation between nurses' age characteristic and their level of knowledge

The current study also revealed that there were a highly statistically significant relation between level of education and knowledge pre-program implementation. This disagreed with Degavi (2013) entitled (Effectiveness of planned teaching programme (PTP) on Knowledge Regarding Cardiac Rehabilitation among staff Nurses working in ICCU of Heart Foundation of KLEs Dr. Prabhakar Kore Hospital \& MRC Belgaum ,Doctoral dissertation, KLE University, Belgaum, Karnataka) who found no significant association between pre-test knowledge scores and educational qualifications.

The study found that, there was statistical significant relation between attending training and total practice, but there was no statistical significant relation between gender and total practice

From my point of view, all nursing staff providing care is encountered with the same circumstances such as large numbers of patients with shortage of staff, limited time, and lack of needed supplies regardless to their personal characteristics so the nurse may have knowledge but don't perform the ideal nursing care.

This was in harmony with Keshk\& Elgazzar (2018) entitled (Creating Learning Guideline for Nurses Caring for Patients Safety Undergoing Cardiac Catheterization) who revealed that a strong positive correlation between the performance of nurses and their qualification regarding the post learning guideline implementation with a statistically significant difference.
The current study also showed that there were statistically significant relation between nurses' practice and their years of experience. This agreed with Henedy \& ElSayad, (2019) who revealed that there was significant statistical difference between nurses' practice and their years of experience.

The current study showed that there was no significant relation between pre-test practice scores and educational level. This agreed with Thomas (2013) entitled (A study to evaluate the effectiveness of video assisted teaching programme on knowledge and practice regarding cardioversion and defibrillation among staff nurses working in cardiac unit in selected hospitals of Bagalkot) who found that there was no significant association between pre-test knowledge scores, pre-test practice scores and educational qualifications. And disagreed with Ali et al. (2015) entitled (Nurses' knowledge and practice regarding implantable cardiac devices in Egypt) who revealed that there were significant statistical differences among nurse's educational levels regarding practice.

The current study revealed that there was a highly statistically significant positive correlation between total knowledge (post and follow-up) and total practice at (post\& follow-up) program implementation. This means that the lack of nurses' knowledge scores effects on their practice regarding care for patient with permanent pacemaker.So, we can conclude that the lack of nurse's knowledge affects negatively on their practice regarding care for patients with pacemaker and their outcomes and all new nurses require training programs in coronary care unit and continuing nursing education regarding care for patient with pacemaker, This was in harmony with Malk et al. (2018) who revealed that there were a positive correlation 
between total nurses' knowledge and practice at post and follow up program implementation.

\section{Conclusion}

There was a statistical significant difference in regard to basic knowledge of the studied sample between pre, post and follow-up the implementation of the educational program $(\mathrm{P} \leq$ 0.05). Also there was a statistical significant differences between the overall practice before, after and follow-up implementing the educational program as $14.3 \%$ of the studied nurse' score was improved to $61.9 \%$ after implementing the program.

\section{Recommendations}

Encourage researchers to implement the program on a large sample size and different areas to evaluate its impact on nurses' performance, provide nurses with continuous educational programs with evidence based guidelines to improve their knowledge and practice related to pacemaker, Evaluating nurses' knowledge and practice periodically to determine the effect of the training programs, Instruct the patients to avoid activities that may effect on pacemaker such as vigorous exercises, Encouraging social agencies to support patients with chronic diseases such as cardiac disease.

\section{References}

Ali, A. S., Mohamed, M. A., Hassan, M. S., \& Sobeh, H. S. (2012). Effect of self learning modules on nurses performance regarding electrocardiography (Doctoral dissertation, Thesis submitted for partial fulfillment of doctorate degree. Faculty of nursing. Ain Shams University).

Ali, N. S., Youssef, W., Mohamed, A., \& Hussein, A. (2015). Nurses' knowledge and practice regarding implantable cardiac devices in Egypt. British Journal of Cardiac Nursing, 10(1), 34-40.
Bakr, A., Shehab, M. S., \& El-Zayat, R. N. (2020). Assessment Of Nurses'performance Regarding Care Of Patients Undergoing Cardiac Catheterization. Port Said Scientific Journal of Nursing, 7(2), 57-77.

\section{Benha annual statistical records (mortality and morbidity rate, 2020), of Benha University hospital}

Catalan-Matamoros, D., Lopez-Villegas, A., Tore-Lappegard, K., \& Lopez-Liria, R. (2019). Correction: Patients' experiences of remote communication after pacemaker implant: The NORDLAND study. Plos one, 14(7), e0219584.

Dalia, T., \& Amr, B. S. (2020). Pacemaker Indications. StatPearls, accessed on 2 July 2021 available on https://www.ncbi.nlm.nih.gov/books/NBK5 07823/

Degavi, G. (2013). Effectiveness of planned teaching programme (PTP) on Knowledge Regarding Cardiac Rehabilitation among staff Nurses working in ICCU of Heart Foundation of KLEs Dr. Prabhakar Kore Hospital \& MRC Belgaum (Doctoral dissertation, KLE University, Belgaum, Karnataka).

Ebada, R., El Senousy, T., Mohamed, S. \& Abdelatief, D. (2017). Effect of Self Care Management on Nursing-Sensitive Patients' Outcomes after Permanent Pacemaker Implantation, Egyptian Journal of Health Care, 8(1), 294-313.

Hassan, N. K., \& Aburaghif, L. F. (2016). Effectiveness of an Educational Program on Nurse's knowledge concerning Complications of Cardiac Catheterization among Children at Al-Nassirhya Heart Center. Kufa journal for nursing sciences, 6(3). 
Henedy, W. M., \& El-Sayad, H. E. S. (2019). Nurses' Knowledge and practice regarding patient's safety Post Cardiac Catheterization, Journal of Nursing and Health Science, 8(3), 43-52.

Jacob, A., Rekha, R.\& Tarachand, J. (2015). Clinical Nursing Procedures: The Art of Nursing Practice, 3rd ed., Jaypee Brothers Medical Publishers, India, 8, 242, 336, 350.

Keshk, L. I., \& Elgazzar, S. E. (2018). Creating Learning Guideline for Nurses Caring for Patients Safety Undergoing Cardiac Catheterization. Research Journal of Education, 4(7), 101-109.

Khudur, K. M. (2019). Effectiveness of an Education Program on Nurses knowledge concerning in Nursing Management for patients with Third degree and bundle branch block in Kirkuk Teaching Hospitals. Mosul Journal of Nursing, 7(1), 7-19.

Malk, R., Rezk, M., Mohammed, S., \& Abd-Allah, K. (2018). Effect of an Education Program on Nurses Performance Regarding Electrocardiography. Egyptian Journal of Health Care, 9(1), 38-49.

Mohammed, O. A., Abd ELstar, M., \& Mohamed, H. A. (2020). Nurses' Performance Regarding Patient with
Permanent Pacemaker in Intensive Care Unit, Journal of Nursing and Health Science, 11(1). Snegalatha, D., Anand, J., Seetharaman, B. \& John, B. (2019). Knowledge and attitude regarding permanent pacemaker and the quality of life of patients after permanent pacemaker implantation, Indian Journal of Continuing Nursing Education, 20(1), 33.

Thabet, E. M., Helmy, H. A., Abdelaziz, M. A. \& Khalf, G. S. (2019). Assessment of Nurses' knowledge And Practices Regarding Temporary Pacemaker patients care. Assiut Scientific Nursing Journal, 7(19), 9-16.

Thomas MP (2013) A study to evaluate the effectiveness of video assisted teaching programme on knowledge and practice regarding cardioversion and defibrillation among staff nurses working in cardiac unit in selected hospitals of Bagalkot. Dissertation, SHRI. B.V.V. Sangha's, Sajjalashree Institute of Nursing Sciences, Navanagar, Bagalkot, Karnataka

WHO. (2017). Cardiovascular disease. World Health Organization, accessed on 5 August 2019, available at: http://www.who.int/cardiovascular_diseases/e n. 
فعالية برنامج تعليمى على أداء الممرضات تجاه العناية بالمرضي المقدمين على تركيب منظم ضربات القلب الدائم

هدى عبدالمنعم السباعى - مروة مصطفى راغب - سماح السيد غنيم

جهاز منظم ضربات القلب هو العلاج الموصى به لعلاج اضطرابات القلب الكهربائية. لذلك هدفت هذه الدراسة إلى تتييم فعالية برنامج تعليمي على أداء أعضاء هيئة التمريض تجاه العناية بالمرضى المقدمين

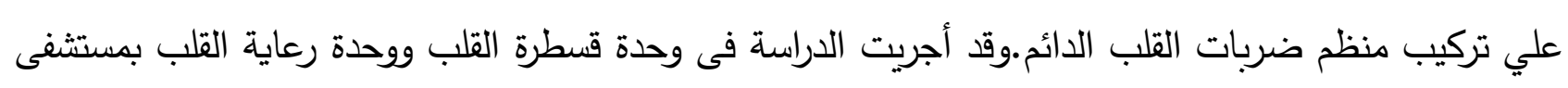
بنها الجامعى على r ك من أعضاء هيئة التمريض، حيث كثفت النتائج أنه فيما يتعلق بمعلومات أعضاء هيئة التمريض ، كان لدى ثلثي أعضاء هيئة التمريض معلومات ضعيفة قبل تتفيذ البرنامج بينما كان أكثر من ثلثي لتئي أعضاء هيئة التمريض يتمتعو بمعلومات جيدة بعد تنفيذ البرنامج وأكثر من نصفهم كان لديهم معلومات جيدة

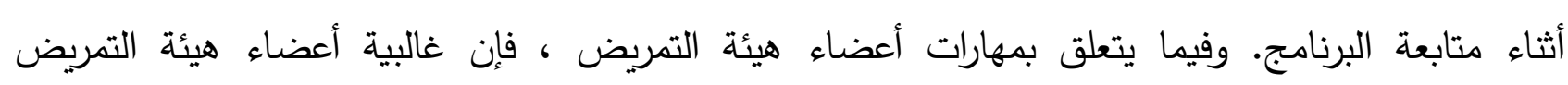

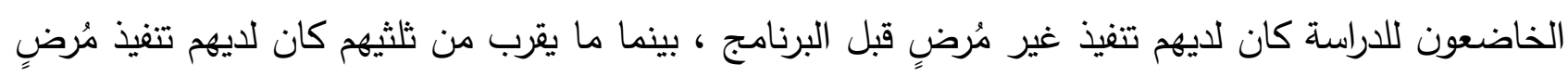

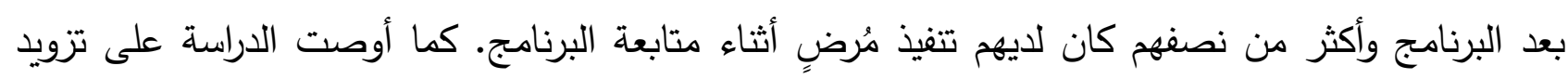
أعضاء هيئة التمريض ببرامج تعليمية مستمرة مع إرشادات قائمة على الأدلة لتحسين معارفهم وممارساتهم المتعلقة بجهاز منظم ضربات القلب. 